\title{
Fonološke baze suškega govora - 120 let po izidu Macedonische Studien (1896) Vatroslava Oblaka
}

\author{
GJoko Nikolovski \\ Univerza v Mariboru, Filozofska fakulteta, Koroška cesta 160, \\ SI-2000 Maribor, gjoko.nikolovski@um.si
}

\begin{abstract}
Prispevek obravnava fonološke baze suškega govora, ki spada v jugovzhodno narečno skupino makedonskega jezika oz. v sersko-lagadinsko podskupino govorov. Ti govori se danes nahajajo v severnem delu Grčije, ki je bil do leta 1912 del etničnega ozemlja Makedoncev. Slovenski filolog Vatroslav Oblak je v letih 1891/1892 raziskoval narečja severno od Soluna in o njih napisal razpravo Macedonische Studien, v kateri je opisal solunski suški govor. Z glasovnimi refleksi, ki jih je našel v suškem govoru, je podprl svojo teorijo o solunski jezikovni osnovi stare cerkvene slovanščine (1895). Prispevek prinaša najsodobnejše stanje fonoloških baz suškega govora, in sicer 120 let po izidu omenjenega Oblakovega dela.
\end{abstract}

The article deals with the phonological base of the Suho dialect, which belongs to the Macedonian south-east dialect group and Serres-Lagadin subgroup of dialects, which today are located in the northern part of Greece, which was until 1912 part of the territory of ethnic Macedonians. The Slovenian philologist Vatroslav Oblak in 1891-1892 studied the dialects north of Thessaloniki and wrote his Macedonische Studien (1896), in which he described the Thessaloniki Suho dialect. The phonological reflexes that he found in the Suho dialect supported his theory of Thessaloniki-based Old Church Slavonic (1895). This article presents the latest state of phonological basis of the Suho dialect some 120 years after the publication of Oblak's Macedonische studien.

Ključne besede: fonološke baze, suški govor, makedonščina, stara cerkvena slovanščina

Key words: phonological base, Suho dialect, Macedonian Language, Old Church Slavonic 


\section{Uvod}

Vas Suho ( $\Sigma o \chi o ́ \varsigma)$ leži v okolici Soluna v Grčiji, njen govor pa umeščamo v jugovzhodno narečno skupino makedonskega jezika ${ }^{1}$ ali natančneje med južne govore navedene skupine, ki se delijo na (1) solunsko-vodenske (dolnovardarske) in (2) sersko-lagadinske govore. Suški govor po svojih temeljnih značilnostih sodi v sersko-lagadinsko skupino govorov in izkazuje visoko podobnost $\mathrm{z}$ govorom vasi Visoka, hkrati pa z govori vasi Balevec, Ilinec in Zarovo tvori manjšo lagadinsko-bogdansko podskupino govorov.

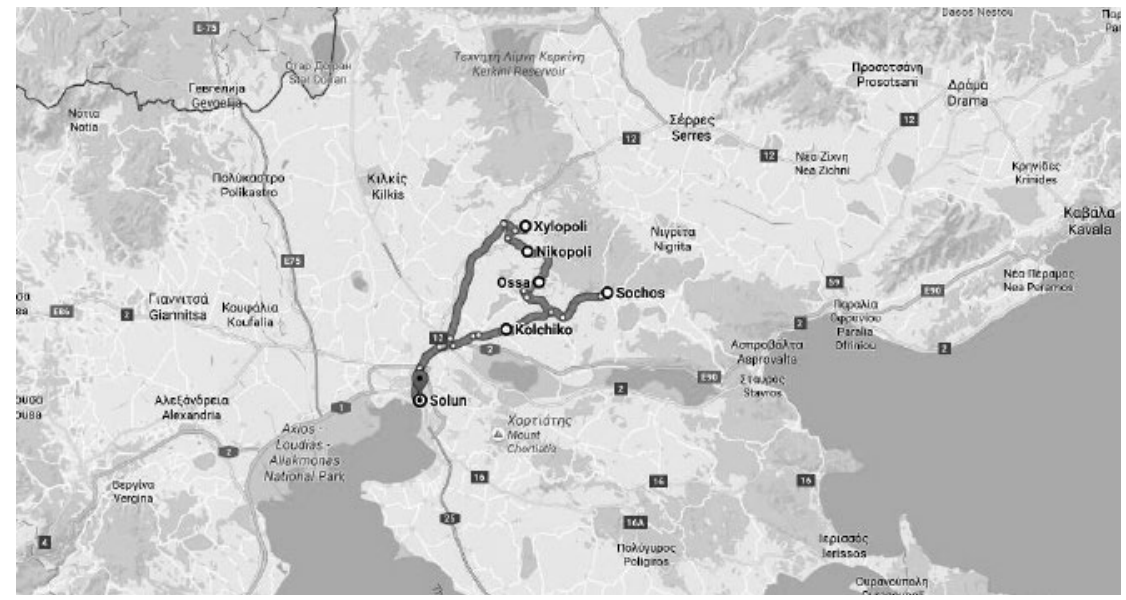

Slika 1: Geografski položaj vasi Suho (Sochos), Visoka (Ossa), Zarovo (Nikopoli), Negovan (Xylopoli), Balevec (Kolchiko) in Soluna (vir: https://www.google.si/maps)

Po statističnih podatkih iz leta 2011 je imela vas Suho 3094 prebivalcev. ${ }^{2}$ Podatka o številu makedonskega prebivalstva ne zasledimo, saj Grčija ne priznava makedonske manjšine. Po ustno pridobljenih podatkih je tam prebivalcev makedonskega porekla okoli 2000.

\footnotetext{
${ }^{1}$ Makedonski jezik ima tri narečne skupine: (1) zahodno narečno skupino, ki se deli na: centralne govore (skopsko-veleški, prilepsko-bitolski, kičevsko-poreški) in zahodne periferne govore (gornopološki, debarski, struški, ohridski, prespanski; drimkolsko-golobrdski; vevčansko-radoški; maloreški (gališki); reški (žirovniški)); (2) jugovzhodno narečno skupino, v katero spadajo štipsko-strumiški govori, tikveško-mariovski govori, maleševsko-pirinski govori, južni govori (solunsko-vodenski (dolnovardarski); sersko-lagadinski govori (dramski, ziljahovski, serski, lagadinsko-bogdanski (govori vasi Suho, Visoka, Balevec, Ilinec in Zarovo; govori vasi Negovan, Ajvatovo in Kireč Kjoj)), kostursko-korčanski govori (korčanski govor, kosturski govor, nestramsko-kostenarijski govor); (3) severno narečno skupino, v katero spadajo kumanovsko-kratovski govori, skopskocrnogorski govor, dolnopološki (tetovski) govor (Видоески 1998; Марковиќ 2001; Марковиќ 2007).

${ }^{2}$ Prim. Hellenic Statistical Authority.
} 


\subsection{Zgodovina Egejske Makedonije in vasi Suho}

Vas Suho je bila do izbruha prve balkanske vojne (oktober 1912-maj 1913) del etničnega ozemlja Makedoncev, ki je bil pod osmansko okupacijo. Zaradi zgodovinskih dejstev (500-letne turške okupacije, različnih podtikanj sosednjih držav, ki so želele uničiti makedonsko identiteto in si prisvojiti makedonsko ozemlje itd.), Makedonci niso uspeli ustanoviti svoje lastne samostojne države (Чепреганов 2008: 211-239). Bolgarija, Črna gora, Grčija in Srbija so leta 1912 oblikovale balkansko ligo oziroma vojaško zvezo ter začele vojno proti osmanski državi za končno osvoboditev izpod turške okupacije. Makedonci so v tej skupni vojni sodelovali z namenom oblikovanja svoje samostojne države. Vojna je prinesla osvoboditev novopazarskega Sandžaka, Kosova, Makedonije in večine Trakije. V ozadju prve balkanske vojne je šlo za razdelitev makedonskega etničnega prostora in Makedoncev na tri dele, tako da bi vsaka od treh držav balkanske lige dobila svoj del. Zaradi nesoglasij glede razdelitve Makedonije je prišlo do druge balkanske vojne (30. junij 1913), in sicer med Bolgarijo na eni strani in Grčijo ter Srbijo na drugi strani. Grčijo in Srbijo sta podprli Romunija in Črna gora, medtem ko je Osmanski imperij še enkrat napadel osamljeno Bolgarijo, da bi si povrnil izgubljeno ozemlje. Vojna je trajala en mesec, in sicer do 31. julija 1913. Uradno se je končala 10. avgusta 1913 v Bukarešti s sklenitvijo mirovnega sporazuma, ki je predvideval novo ozemeljsko razdelitev, in sicer je Romunija dobila Južno Dobrudžo, Vardarska Makedonija je pripadla Srbiji, Egejska Makedonija Grčiji, Bolgarija pa je izgubila del Zahodne Trakije (ozemlje je pripadlo Grčiji) (Чепреганов 2008: 227-239). Po drugi balkanski vojni so se Makedonci v Egejski Makedoniji srečali z najtežjim obdobjem v svoji zgodovini. V obdobju od leta 1913 do leta 1928 je Grčija nad Makedonci izvajala močno kolonizatorsko politiko, s čimer je spremenila etnično podobo celotnega območja. Med grško ljudsko vojno, ki je trajala od leta 1945 do leta 1949, se je štirinajst tisoč Makedoncev povezalo v Demokratično grško vojsko, temu pa je sledil val nasilnih preganjanj, umorov in mučenj s strani grških oblasti. Število Makedoncev in drugih negrških etničnih skupin se je spreminjalo iz leta v leto. To je razvidno iz podatka o številu Makedoncev, ki je leta 1904 znašalo $896.494,{ }^{3}$ leta 1949 pa $195.395 .{ }^{4}$

\subsection{Suški govor in vprašanje jezikovne osnove stare cerkvene slovanščine}

Suški govor je postal zanimiv v drugi polovici 19. stoletja, tj. v času kulminacije vprašanja o jezikovni osnovi stare cerkvene slovanščine, ki se je prvič pojavilo na prelomu iz 18. v 19. stoletje. Odgovor na omenjeno vprašanje je bil podan v obliki dveh teorij: (1) panonske (karantansko-panonske), ki sta jo zagovarjala

\footnotetext{
${ }^{3}$ Prim. DM Brancoff 1905.

${ }^{4}$ Prim. Lazo Moïsov, Sur la question de la minorité nationale macédonienne en Grèce.
} 
Jernej Kopitar in Franc Miklošič, ter (2) makedonske (makedonsko-bolgarske ali solunske) teorije, zagovarjane s strani Vatroslava Jagića in Vatroslava Oblaka (Jesenšek 1998: 25; Babič 2003: 18-19; Šekli 2014: 106-108).

Jernej Kopitar (1780-1844) je v prvi polovici 19. stoletja svetemu jeziku Slovanov pripisal panonsko osnovo. Svojo teorijo je oblikoval kot odgovor na teorijo, ki jo je v tem času zagovarjal Josef Dobrovský (1823). ${ }^{5}$ Kopitar je svojo teorijo dokazoval na podlagi etimološke analize starocerkvenoslovanskega besedja, v katerem je odkril veliko latinskih ali nemških izposojenk, na primer олтарь, lat. altar, оцьтъ, lat. acetum, постъ, svn. Faste, попъ, svn. Phaph. Sklepal je, da so bile te besede prisotne samo v slovanskem govoru, ki so ga govorili blizu latinsko-nemških območij (Kopitar 1836: VIII-IX). Njegov učenec Franc Miklošič je Kopitarjevo teorijo nadgradil z dodatnimi jezikovnimi argumenti, na primer obstojem nosnikov $(\boldsymbol{x}, \mathbf{A})$ in soglasniških skupin шт in жА v madžarskem jeziku v izposojenkah slovanskega porekla (npr. pentek, madž. : Патъкъ; szombota : сжвота; mozstoha, rozsda, Budapest), ki naj bi bile prevzete iz sosednjega slovanskega oziroma slovenskega jezika (Miklošič 1874: IV).

Vatroslav Oblak je ob koncu leta 1891 odšel na študijsko potovanje po južni Makedoniji in tam preučeval narečja solunske okolice in mesta Debar v zahodni Makedoniji. Rezultati njegovega raziskovanja so bili objavljeni v delu Macedonische Studien (1896). V tem delu je Oblak opisal makedonsko-solunski govor vasi Suho; izpostavil je, da je v njem našel refleksa $\check{s} t$ in $\check{z} d$ za psl. * $t j$ in *dj. Pred izidom tega dela je v Ljubljanskem zvonu (1895: 237-246, 306-317) objavil Književno poročilo o delu Zgodovina slovenskega slovstva avtorja Karla Glaserja in v njem predstavil svojo teorijo ter jo podkrepil z jezikovnimi argumenti, med katerimi je glavni obstoj soglasniških skupin $\check{s} t$ in $\check{z} d$ v solunskem suškem govoru. Kasneje je njegovo teorijo potrdil tudi njegov mentor Vatroslav Jagić, in sicer v delu Zur Entstehungsgeschichte der kirchenslavischen Sprache (1900 in 21913: 270-273).

Za Oblakom je poljski jezikoslovec Mieczysław Małecki (1903-1946) zbral gradivo iz suškega in visoškega govora ter ga objavil v Dwie gwary macedońskie (Suche i Wysoka w Soluńskiem) - Teksty (1934) in Dwie gwary macedońskie (Suche i Wysoka w Soluńskiem) - Stownik (1936). Njegov učenec Zbigniew Gołąb (1923-1994) je na podlagi tega gradiva opravil zadnji opis širšega suško-visoškega govora (Голомб 1960/61: 113-183; 1962/63: 173-277). Kasneje je Božidar Vidoeski sestavil fonološke baze visoškega govora, in sicer na podlagi gradiva, ki ga leta 1934 zbral in objavil Mieczysław Małecki (Видоески 2000).

S seznama navedenih avtorjev, ki so raziskovali suški govor, je razvidno, da ni bil nihče izmed njih makedonskega rodu ali naravni govorec makedonskega jezika.

${ }^{5}$ Josef Dobrovský je leta 1823 v svoji študiji Cyrill und Method der Slaven Apostolen: Ein historisch-kritischer Versuch za osnovo stare cerkvene slovanščine predlagal »staro še ne ločeno srbsko-bolgarsko-makedonsko narečje«, kar je razvidno iz zapisanega »der alte noch unvermischte serbisch-bulgarisch-makedonische dialekt« (Dobrovský 1823: 133; Šekli 2014: 106). 


\section{Okoliščine zbiranja gradiva}

Zbiranje gradiva, predstavljenega v prispevku, je potekalo v dveh etapah (julija 2011 in julija 2013), in sicer v težkih okoliščinah, ki so odraz že predstavljenih zgodovinskih okoliščin Egejske Makedonije. Prebivalci vasi Suho zaradi strahu nastopajo z nezaupanjem do ljudi, ki želijo raziskovati njihovo življenje (zgodovino, jezik, kulturo itd.). S pomočjo Pavleta Voskopulosa, predsednika politične stranke makedonske manjšine Vinožito v Grčiji, ki sem ga spoznal leta 2011 v Bitoli, sem prišel do kontakta Giorgosa Koftisa, ki mi je bil pripravljen pomagati pri zbiranju gradiva, ker se tudi sam ukvarja z opisovanjem življenja in jezika Makedoncev v vasi Suho. Že na samem začetku je opozoril, da bo zbiranje gradiva potekalo oteženo, saj makedonski prebivalci vasi zaradi težav v preteklosti niso sproščeni niti naklonjeni odgovarjanju na vprašanja $\mathrm{v}$ zvezi s svojo zgodovino, jezikom itd. S pomočjo Giorgosa Koftisa sem uspel prepričati nekaj starejših prebivalcev, da so spregovorili v svojem jeziku in povedali različne zgodbe iz svojega življenja, pri tem pa ni bilo priložnosti, da bi gradivo v celoti zbral in zapisal po vprašalniku. Pridobljeno gradivo sem v naslednji fazi transkribiral in analiziral. Pred zaključkom analize fonoloških baz je bilo ugotovljeno, da manjkajo primeri za posamezne reflekse, zato sem pripravil seznam besed, ki sem jih našel pri Oblaku (1896) in Małeckiju (1934), ter jih prevedel v grščino, da bi lahko v naslednji fazi (julija 2013) s pomočjo Giorgosa Koftisa od informatorjev pridobil makedonsko ustreznico za vsako grško besedo. S tem sem uspel zaokrožiti opis fonoloških baz suškega govora.

\section{Fonološke baze suškega govora ${ }^{6}$}

\section{INVENTAR}

\section{VOKALIZEM}

$\mathrm{V}$ naglašenem položaju

$\begin{array}{lll}i & & u \\ e & \text { o } & \\ \ddot{a} & & \end{array}$

\footnotetext{
${ }^{6}$ Fonološke baze suškega govora so sestavljene po modelu fonoloških baz visoškega govora v delu Fonološke baze govorov makedonskega jezika (Фонолошките бази на говорите на македонскиот јазик) Božidarja Vidoeskega (Видоески 2000), ki jih je pripravil na podlagi gradiva, ki ga je zbral in objavil Mieczysław Małecki (1934) (Видоески 2000: IV). Primeri, ki jih Vidoeski navaja v opisu fonoloških baz visoškega govora, so preverjeni na terenu v vasi Suho, in sicer v drugi fazi zbiranja gradiva. Visoški in suški govor sta zaradi visoke stopnje podobnosti v makedonski dialektologiji obravnavana kot širši suško-visoški govor (Видоески 1999: 76-79).
} 
Vsi samoglasniki v nenaglašenem položaju so pod vplivom kvalitativne redukcije, ki je rezultat močnega ekspiratornega naglasa. Rezultat navedenega je naslednji sistem samoglasnikov:

$\partial$

Iz navedenega sledi, da prihaja do poenostavljanja oziroma eliminacije opozicij: $e: i, o: u, a:$, medtem ko $\ddot{a}$ preide $\mathrm{v}$ reducirani samoglasnik $a$.

Samoglasnik /a/ v nenaglašenem položaju se izgovarja nižje od naglašenega $\mid \partial /$, kakor srednji glas med $/ a /$ in $\mid \partial /$, vendar nižje kot $|a|-[a]$.

\section{KONZONANTIZEM}

Zvočniki

$\begin{array}{cccc} & & & m \\ & & & m \\ & l & r & n \\ & l & r & n \\ j & & & \end{array}$

Nezvočniki

$\begin{array}{llll}p & b & f & v \\ p & b & f & v^{\prime} \\ t & d & & \\ t^{\prime} & d & & \\ c & d z & s & z \\ c & d z & s^{\prime} & z \\ \check{c} & d \check{z} & \check{s} & \check{z} \\ k & g & h & \\ k & g & & \end{array}$

Ustnično-zobni izgovor $/ v /, / v /$ : are's'suva, ču'vläk, 'dva, 'dvete, fuk'nuva, hubạ'vičcko, kak'vo, kaj've, 'kazvam, ot'i'va, ot'i'vahme, P'etrah'i'voto, prome'narstvo, 'stava, stova'raha, 'vank, ve'l'im, vero'nata, ve'rn'jạ, vit'liš, 'zvei, ži'vin'i.

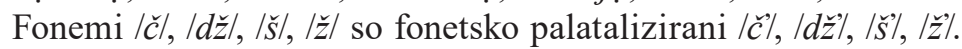

Mehčani $/ h /[h]$ se pojavlja kot alofon $/ h /$ pred /i/: 'dreh'i, h'i'l'ada, mạ'i'neto, or'ah'i, s'iro'mah'i, 'suh'i. 


\section{ProzodiJa}

Naglas je svoboden in spreminjajoč se, na primer 'brada - brạ'datạ, 'bera b'i'reš, glas - glạ'sot, 'kosme - kos'meto - kos'menta - kosmen'tata.

\section{DISTRIBUCIJA}

\section{VOKALIZEM}

Vsi samoglasniki v nenaglašenem položaju so pod vplivom kvalitativne redukcije, ki je rezultat močnega ekspiratornega naglasa. Samoglasniki se izgovarjajo krajše kot primerljivi naglašeni samoglasniki in včasih v srednjih zlogih pred soglasniki povsem izginejo.

Samoglasnika /e/, /o/ v nenaglašeni obliki sta v vseh položajih besed pod vplivom kvalitativne redukcije in po pravilu prehajata v primerljive višje samoglasnike: du'b'ituh, 'čendu, či'n'ica, ču'ban, čur'ba, 'čuv'äk, 'd'ivi'ro, 'd'ir'és, du'lo, du'ma, gr'in'data, gu'd'in'i, gu'l'em, gu'ra, ku'ga, ku'r'em, ku'zata, lu'kum, mu'retu, n'i'd'el'a, n'i'ma, polu'v'ina, 'pu'l'etu, ugl'in'dalu, lu'że, 'mozuk, 's'elu, ši'k'er, t'il'iffono, tu'gas, už'en'i, z'il'eno.

Nenaglašeni /ä/, /a/, /a/ se realizirajo kot srednji glas med/a/ in /a/, najbližje drugemu $[a]$. To pomeni, da se v nenaglašeni obliki izenači izgovor omenjenih treh fonemov in izgine nasprotje med /a/ in /a/ ter med /a/ in /ä/: a 'rap, as 'k'er'in, bạh'ča, bạn'dzot, 'bašta , bạ'rata, c'ád'iš : 'c'äd'ạ, čạr'šaf'e, čạr'ven, čar'veno, dạs'katạ : 'doska, 'dəš : dạžd'i, jablə'katal'jablạ'kata, l'ạ'ta : 'lätu, lon'džička, m’ạ'sa : mäsu, mạn'džoi : monč, rạ'kata : 'r'äka, rạš'ta : rəšs, sf'ạš́ta : sf'äš, sf'ạ'to : sf'ät, sn'ạ'go : sn'äk.

Iz zgoraj prikazanega sledi:

- fonema $/ i /, / u /$ lahko stojita v nenaglašenih in naglašenih oblikah: bo'l'i, brạt'čend'i, 'čijne, čur'ba, 'druk, du'ma, 'ed'in, gu'l'em, hlo'puta, hu'bav, ig'rime, im'enta, ku'rem, lakar'd'ijạ, 'l'ud'i, lu'kum, n'i'd'el'a, 'n'isko, no'žul'ka, pa'puto, ši'k'er, uš'ite, už'en'i;

- fonem /a/ se v osnovnem alofonu realizira v naglašeni obliki, v nenaglašenem položaju v alofonu [ạ]: $d \partial \check{s}-d a$ I $^{\prime} \check{d} d^{\prime} i$, 'mənč - mạn'džoi;

- fonema $/ e /, / o / \mathrm{v}$ nenaglašeni obliki sta nevtralizirana $\mathrm{z} / \mathrm{i} / \mathrm{l} / \mathrm{u} / \mathrm{,} \mathrm{v}$ posameznih primerih se lahko srečata tudi zaprta alofona $[e, o]$, in to predvsem $\mathrm{v}$ tujih besedah: b'ẹr'b'erin, čọ'lak, 'čotra d'ẹ'mek, lọ'k'um, pạn'talọn, p'ẹr'd'e, pẹr'dänata, pọ'lata;

- fonem /ä/ se realizira samo z naglasom, v nenaglašeni obliki ima alofon $[a]$ z različnimi stopnjami redukcije: pogo'l'äma - pogol’a'mit'e - pogol’’'mata;

- fonem /a/ se prav tako v svojem osnovnem alofonu pojavlja samo z naglasom, v nenaglašeni obliki pa se realizira višje, je bolj zaprt [a] : 'daskạl-dạs'kalo - daskạl'eto.

Glede na soglasnike se omejena distribucija kaže samo pri fonemih /ä/ in /ə/. Prvi fonem s svojima alofonoma $[\ddot{a}, a]$ omehča predhodni soglasnik in se 
pojavlja samo za palataliziranim soglasnikom: b'äl, d'äl, 'l'ätu, 'noz’ạ, no'zä̈ta, 'n’äštu, 'p’än, 'räpa, s'änka, sf'ät, šár'äni, 'v'ära, żäš.

Fonem /a/ se praviloma pojavlja samo za trdim soglasnikom: 'bə, bək'reto, da'ždaše; 'dənii, 'dəsk'i, 'dənp, obəgu'vaše, zạ'bəlvam.

V skupini jezičnikov /r/, /l/ stoji samoglasnik /a/ vedno na začetku za jezičnikom, na primer landže, 'laska, 'ranka, rəš, 'rəždạ. V sredinskih zlogih lahko stoji za jezičniki in pred njimi, odvisno od števila soglasnikov in značilnosti soglasniške skupine: 'dlag'i, dlakačạk, garčllivii, 'garlu, 'karl'iš, 'karsti, mal'čah, 'zarnu; 'slance, tran, v'raba, ali 'pal'in, 'valk, 'valna - d'langu, s'laba, s'lanc'e, 'zolva.

Skupine $\mathrm{z}$ dvema samoglasnikoma niso pogoste. Tudi tiste, ki jih najdemo $\mathrm{v}$ gradivu, so pretežno v tujih leksemih, v domačih samo v primeru, ko se je izgubil kak soglasnik v medsamoglasniškem položaju in na morfemski meji s predlogom: 'baiš, bru'iš, ča'ušin, 'gaur, mạ'uka, 'moiš, nai'noš, nạ'okul, nạ'opaku, 'neuk, 'nou, 'par'ẹa, p'raiš, 'prait, 'praehạ, p'rau, 'sea, tru'ica, 'zainc, zaii'noš.

Skupine dveh istih samoglasnikov so prav tako redke. Na terenu je bilo najdenih le nekaj primerov: kabạ'at, 'znaat, 'klaạm, mạ'beet 'praạ, 'šeejs.

Skupine treh samoglasnikov v gradivu niso potrjene.

Redki so primeri s krčenjem dveh samoglasnikov. Najdemo naslednje primere: p’äm (p'äeš), 'sa:to, tkaš (tkaeš), šišs (šieš), l'en' (< l'een < l'egen), vä̈s (v'äeš), zäš/z'äišs.

\section{KONZONANTIZEM}

Glede na položaj v besedi so omejeni samo zveneči nezvočniki, ki ne morejo stati na izglasju. Zvočniki in nezveneči nezvočniki lahko stojijo v vseh položajih: 'druk - 'drugạ, 'dənp - dan'b'ic'i, 'gol', 'kl'učo, ko'kal'o, 'luk, po'zdrav'i, 'zdraf - 'zdrave.

Ni zaporedja med zvenečimi in nezvenečimi nezvočniki. Zveneči nezvočniki ne morejo stati pred nezvenečimi, nezveneči pa ne morejo stati pred zvenečimi.

Soglasniki $|\check{c} /|, d \check{z} /,|\check{s} /,| \check{z} /$ se ne glede na položaj samoglasnikov izgovarjajo rahlo palatalizirano: 'čista, 'čičko, dži'boto, imạ'še, 'mənč, 'mandža, pạ'ždaše, sf'i'raše, 'šes, ži'vot.

Pred sprednjimi samoglasniki /i/, /e/, /ä/, vključujoč vse njihove alofone, se izgovarjajo palatalizirani soglasniki: ču'v'äk, d'if, dobre, 'dveté, 'ed'in, gol'ema, 'kravii, 'lepče, p’is'mo, si'rence,e, 'tri i, v'elli, ve'čero, ze'mata že'n'i.

Pred zadnjimi samoglasniki $/ a /,|o /|$,$u / lahko stojijo tako palatalizirani kot$ nepalatalizirani soglasniki: 'b'älo - 'b'äl'i - b'äl, 'bratạ, 'gol', 'dunạ, 'inalina, 'kola, 'kl'učo, lo'kumia, lok̉um, 'mravạ, 'mračvạ, ná'umaha, rạ'botạ, 'stran'a, tu'tun, sur'tuk, 'umn'a - po'umria.

Mehkost je lahko razločevalna tudi na koncu, na primer żent 'zemen', żent' 'zet', kat : kat', l'en : l'en' 'legen'. V posameznih primerih je mehkost naključna s tendenco, da se izgubi, na primer bu'nar - bu'naro, pa'zar - pa'zaro, 'toplo - 'toplo. 
Pred soglasniki palataliziranih fonemov se lahko pojavi samo /l\%, in to redko: 'lul'ka. Pri drugih soglasnikih se nasprotje trdi : mehki nevtralizira v korist prvih, na primer s'f'in'a : s'f'insk'i, sol' : sul'ta, kon' : 'konsk'i.

\section{Soglasniški sklopi}

Na vzglasju se lahko pojavljajo zvočniški sklopi $m l-, m l$ '- in $m r-$ : 'mlado, 'ml'askạs, 'mləskạ, mləči, 'mləčva, 'ml'äko, 'mrava, 'mrzol.

Sklop $m n$ - ni možen $(>m l)$, na primer 'mlogo/'mlogu.

Vzglasne skupine zvočnik + nezvočnik ni.

Soglasniški sklop vn- ni ohranjen (>øn): nuk, 'nuka, 'nuc'i, 'notrạ, 'n'etr'e, medtem ko je soglasniški sklop $p \check{c}-\mathrm{v}$ določenih primerih ohranjen, npr. 'pčela (tudi 'pšelạ), pče'n’ica, ali poenostavljen v /č/: čin'ica - či'n'iči $i$. Soglasniški sklop $p s$ - se ohranja: p'sovanii, psalt, p'salav.

$\mathrm{Na}$ izglasju so redke skupine -st, -št, na primer dəš, krəs, p'ěs, 'radus, šes, 'zapos, vendar most, post.

Od drugih soglasniških sklopov niso možni še $s r$-, zr-, žr- (>str-, zdr-, ždr-): stram, st'r'ädạ, st'r'ädnu, st'rošta, st'r'ät’im, st'rac'i 'srce', zdr'äl, zd'r'äpča.

$\mathrm{V}$ največ primerih izginja tudi medglasni sklop -vn- $(>-m n-)$ : p'rəmnạ, osəm'nuvạ/u'səmnuva, 'ramnu, gum'no, p'l'ämnạta.

Obstaja težnja po izginjanju sklopa $d n$, na primer 'ena, 'enạš, 'panạ, 's'ejnu, 's'ena. Sklop /dv/ je ohranjen: ize'dvahme, ot'kradva, enako /tv/ 'tvoje.

Sklopi dveh istih soglasnikov niso zabeleženi.

\section{Posamezni soglasniki}

Fonem /j/ je v omejeni distribuciji prisoten na začetku besed. V tem položaju ne more stati pred sprednjimi vokali, na primer i'c'e, i'd'en'i, 'id'e, 'el'in, 'endru, 'entrạvạ, 'enz'ik, v medsamoglasniškem položaju pred istimi samoglasniki pa se /j/ praviloma pojavlja: nạ'duji, 'vraji, 'zm'iji, 'znaji.

Zvočnik /j/ se ne pojavlja za palataliziranimi soglasniki: h'il'ada, lo'z'a, 'snop'ạ, 'zdrave, 'zele z'emața.

Fonem / $/ /$ na koncu in pred soglasnikom se fakultativno spreminja $\mathrm{v}$ alofon

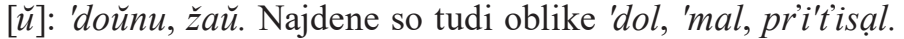

Fonem /l'/ se pojavlja brez omejitev: 'gol'o, ko'šul'ạ, l'äp, 'l'el'a, 'l'irạ, 'l'ul'ạ, l'ul'ka, l'uš, 'ml'äko, s'il'an'i, sol', l'ub'énica, 'luk, 'zel'e.

Soglasnik $/ n /$ pred $/ k /, / g /$ se realizira kot nosni soglasnik, ki ga zapisujemo $\mathrm{z} / \eta /$ in /an/: ay'gar'ija, frayk, 'majka, 'məngla, 'pajạk, 'ronka, 'vənk.

Zvočnik / $r /$ se nikoli ne pojavlja v skupinah $r C$ - in $\mathrm{CrC}$.

Soglasnik $/ v /$ se pred labializiranimi samoglasniki na začetku in v medsamoglasniškem položaju izgovarja kot v: p'ravu, 'voda, ži'vot, vosok, vendar 's'ičk'i.

Glede na sosednje soglasnike $/ v /$ ne more stati za nezvenečim nezvočnikom, na primer 'bənčfạ, s'f'äšta, s'f'insku, s'f'ir'ạ, sf'i'raše, 't'ikfạ, 't'ikf'i, 'žentfạ. 
Fonem /dz/, ki je precej redek, ima prav tako zelo omejeno distribucijo. Najpogosteje se pojavlja v skupini z /n/: dz'in'g'isko, in'dz'ik, 'pajandz'i, pál'andza, vandz'il'if, 'vandz'il', v posameznih primerih tudi pred samoglasnikom: 'budza, c'i'dzalnik 'cedalo', 'dzadnu, 'dzidạm, dz'im'b'il', dz'in'g'ijạ 'uzengija', u'dzat, udu'dzat.

Fonem /dž/ se pogosto pojavlja skupaj z/n/ in v prevzetih besedah: bạ'džanạk, džumạli'jatạ, čendže'rata, k'i'radžii, 'landže, lan'džijạ, 'mandža, m’in'džit.

Fonema $/ k^{\prime} /, / g /$ sta zelo redka. Pojavljata se v prevzetih besedah. Stojita lahko pred vsemi samoglasniki in na izglasju: b'ir'i'k'at, dju'šejk', 'gak'i, gol', g'ub're, g'um, i'l'ejk', il'mek', k'ef, k'ir'im'i'd'et'e, k'uf't'e, k'u'tek, lak'.

\section{ProzodiJa}

Paradigmatske besede razlikujejo dva osnovna naglasna tipa: (1) paradigma z morfološkim fiksiranim naglasom, na primer 'baba - 'babata - 'bab'i-'bab'ite, 'v'ikam - 'v'ikăš - 'v'ikame - 'v'ikat, in (2) paradigma s prilagodljivim naglasom. Prilagodljivost naglasa se kaže pri naslednjih morfoloških tipih: (a) pri samostalnikih: 'd'ät'e - d'ä'ca - d'ä'teto - d'ä'catạ; 'koža - ko'žatạ; 'kosme - kos'meto - kos'menta; 'ofca - 'ofc'i - of'catạ; 'zomp - 'zamb'e - 'zamb'i - 'zamb'a - z a'b'it'e - zamb'äl'eto; (b) pri glagolih: 'gl'enda - 'gl'endam-gl'en'daš - 'gl'endaj - gl'en'daše - 'gl'endạh - gl'en'daha .

Če bi moral biti naglašen četrti zlog od konca proti začetku besede, se v besedah s štiri ali več zlogi na predzadnjem zlogu pojavi drugi naglas, ki je po intenzivnosti enak prvemu, na primer 'car'ica : 'car'i'catạ, 'glasu'vetu, 'jagni'čantạ, 'kažu'vaha, 'košni'catạ, 'kožuv'u : 'kožu'vetu, 'lobu'datạ, 'negu'vajut.

\section{IZVOR}

\section{VOKALIZEM}

Samoglasniki /i/, /e/, /a/, /o/, /u/ izvirajo iz ustreznih samoglasnikov v spodnjem sistemu. Ob tem je za njihov izvor značilno še sledeče:

$i \leftarrow e$ v nenaglašenem zlogu: či'n'ica, 'ed'in, i'l'en, n'i'd'el'ạ, sf'in'tec, ši'k'er.

$e \leftarrow{ }^{*}$ : d'en', l'ek, l'eka, l'eku, l'en, l'enu, sfin'tec(u), sfin'teci;

$\leftarrow{ }^{*} e$ : 'mesu, najpogosteje $\mathrm{v}$ skupini $\mathrm{z} / n, m /$ : brạt'čend'i, 'čendu, 'endru, en'trava, 'gl'enda, g'renda, ir'en'b'ica, k'l'entfạ, ko'l'enda, m’ins'i'čina, magạ'rento, 'meyka, nạ'renduvam, 'p'end'a , pent', 'p'enta, p'en'tata, 'pentuk, 'rent, 'zent, 'žentfạ;

$\leftarrow$ *ě v posameznih leksemih z naglašenim zlogom: 'tera, 'vedru, vek;

$\leftarrow$ drugotno v skupini čer-: 'červạ, čẹr'va 'opinci', čẹ'r'äšạ; najden je bil tudi primer čre'jašạ.

$\ddot{a} \leftarrow$ *̌̌ v naglašenem zlogu: br'äk, 'b'ägạm, 'čov'äk, 'd'ädu, 'd'äte, 'l'äp, 'l'ätu, 'm’äso, 'm’ästu, 's'äjme, 'sänkạ; 
$\leftarrow{ }^{*} e \mathrm{v}$ posameznih primerih, najpogosteje v skupini z /n/: 'mä̈lka, 'mänca, ku'čäntạ, v nenaglašenem zlogu: 'jagn'ạ, 'jạgnạntạ, v'r'äme;

$\leftarrow a \mathrm{za}|\check{c} /,| \check{s} / \mathrm{v}$ posameznih primerih, na primer 'čäju, 'čäšă , 'šäjka, 'šärka (vedno $\mathrm{v}$ naglašeni poziciji).

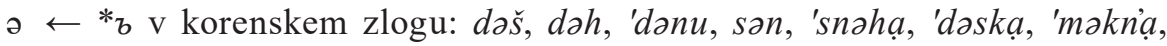
'səhnuvam;

$\leftarrow{ }^{*} Q$ v korenskih morfemih: 'gaska, 'kəšta, 'mətnu, 'rəka (obstaja tudi 'ranka), in v skupini z /m/ pred ustničnikom: 'gambạ, dlam'boko, dəmp, pəmp, ramp, 'tampạn, 'kampạt, 'ramb'iš, 'skampi, 'sambotạ, zamp ter v skupini z /n/: drank, 'grandi, 'danp - dən'b'ic'i, g'rand'a, 'kandu, kant, lank, mənč, 'mondru, 'mənka, sa 'mənčiš, pront', p'rančka, pan't'ičkạ, 'ranka 'ranc'a - ron'kata, rən'kaf, 's'äkand'ạ, 'sand'iš, sank, sant;

$\leftarrow$ sekundarni $b_{2}$ : alon'džijạ, 'bančfa, 'dlanga, 'londže, lạn'dža, lạn'džica, lan'džičkạ, lạn'džif, 'manglạ;

$\leftarrow r$ v skupini z $r$ : 'brašnil, čet'vartak, 'garlu, grạn'čarin, 'hraskạm, kạt'arkạ, 'karsti, tran, v'raba, 'var'a, 'zarnu;

$\leftarrow$ *l: d'langu, 'jablak'i, mal'čah, s'lanc'i, s'laza, 'valna, vlak, žzlt;

$\leftarrow a, \ddot{a} \mathrm{z}$ redukcijo v nenaglašenem zlogu;

$a \leftarrow *_{e} \mathrm{v}$ posameznih leksemih: 'cal, l'ap, 'l'atạ, 'ṕasuk;

$\leftarrow{ }^{*} Q \mathrm{v}$ končnicah in fleksibilnih morfemih: 'd'igam, ot'ihal, pr'i'tisạl.

$u \leftarrow o$ z redukcijo v nenaglašenem zlogu: čur'ba, du'ma, gu'ra, gu'l'em, ku'rem;

$\leftarrow i$ z labializacijo za $\check{c}, \check{s}$, ž, neregularno: ču'buk, čuf'čijạ, čum'ber, ču'men', čumer, 'čungul, ču'vijạ, čuv're, šur'b'et, žuf;

$\leftarrow$, ko so v bližini ustnični soglasniki v posameznih primerih: pump 'pumpuvi, 'pumka, nạ'pulnuvam.

$o \leftarrow{ }^{*} b_{\circ} \mathrm{v}$ morfemih s spono, na primer gạr'nok, vạ'ko, d'en'd'i'no.

\section{KONZONANTIZEM}

Soglasniki $|j|,|l|,|r|,|m|,|n|,|v|,|p|,|b|,|d|,|c|,|z|,|\check{c}|,|\check{s}|,|\check{z}|,|k|,|g|, \mid h /$ izvirajo iz ustreznih soglasnikov v izhodiščnem sistemu s pozicijo pred sprednjimi samoglasniki in $\mathrm{v}$ nekaterih drugih primerih (prim. spodaj), kjer preidejo $\mathrm{v}$ palatalizirane soglasnike. Palatalizirani soglasniki $\left|\mathrm{m}^{\prime}\right|,\left|\mathrm{n}^{\prime}\right|,\left|l^{\prime}\right|,\left|\mathrm{r}^{\prime}\right|,\left|\mathrm{p}^{\prime}\right|,\left|b^{\prime}\right|,\left|f^{\prime}\right|,\left|v^{\prime}\right|$, $\left|t^{\prime}\right|,|d\rangle,|c|,\left|d z^{\prime}\right|,|s\rangle,\left|z^{\prime}\right|$ izhajajo iz primerljivih trdih soglasnikov pred sprednjimi samoglasniki /i/, /e/, /ä/. Več teh glasov ohranja staro palataliziranost in palatalnost v drugih položajih besed: pred samoglasnikom /a/ v 1. osebi ednine in $\mathrm{v}$ 3. osebi ednine v sedanjiku glagolov $i$-skupine, na primer 'umia, 'umạt - 'um'iš,

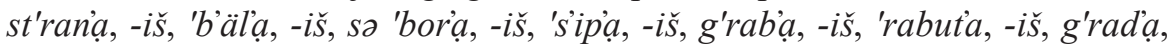
-iš, 'kos'a, -iš, na koncu pred malim $b$, na primer d'en', sol', d'evit', pant', p'ent'. $\mathrm{V}$ posameznih primerih so palatalizirani soglasniki pridobljeni po analogiji, morfološko, kakor na primer v 1. osebi ednine sedanjika pri glagolih tipa: 'kaln'ạ

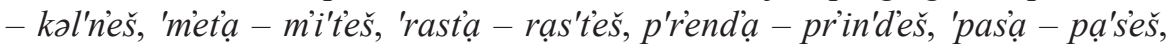
'd'erạ - di'réš, p'lav'a - plạ'vešs (tematski soglasnik se poenoti pri vseh osebah). 
Poleg tega:

$j \leftarrow i$ za drugim samoglasnikom v ločenih primerih, na primer puj'na/'pojna (< poina > po edna), 'plajna (pladnina).

$\leftarrow e$ pri števnikih, na primer id'i'najst'ilid'i'najs'e, dva'najse, dvạ'najst'i, 'dvajst'i, 'tr'ijst'i.

$\leftarrow$ za zapolnitev hiata v primerih kot: 'cäjạ, k'lajạnc, 'hubajạ, p'rajạ, 'ostạjạ, us'tajam.

$\leftarrow$ v skupini s $k^{\prime}\left(j k^{\prime}\right)$ na koncu prevzetih leksemov: cu'rajk', i'l'ejk', ku'najk, l'u'l'ajk'.

$\left.l \leftarrow{ }^{*}\right]_{0} \mathrm{v}$ skupini z lal: mal'čah, 'salnc'e, 'slaza, 'valk, 'valnạ, 'zalvạ.

$\leftarrow$ l'na koncu v posebnih primerih, na primer 'kənkul, sạn'dal, 'vəndz'il, žal.

$l \leftarrow * l b:$ sol;

$\leftarrow$ lj: h'il'adạ, 'l'il'ạk.

$r \leftarrow{ }^{*} r$ v skupini z /al: 'garlo, 'karsti i 'vraba, 'zarnu.

$m \leftarrow{ }^{*} e$ v zaporedju $e m>$ im pred ustničnim soglasnikom: ir'im'b'ical ir'en'b'ic'i;

$\leftarrow{ }^{*} Q$ v zaporedju am pred ustničnim soglasnikom: damp, dlam'bok, 'gamba , 'kəmpạt, 'pəmp, 'rəmbiš, 'skamp'i, 'sambutạ/səm'botạ, 'təmpạn, 'zəmp;

$\leftarrow v$ v zaporedju vn: 'osamne, 'pramnu.

$m \longleftarrow{ }^{*} m$ pred $j$ : 'lamá, z'e'mata.

$n \leftarrow{ }^{*} e$ v zaporedjih en, än, pred nelabialnim soglasnikom: 'endru, en'trava, 'meyka, 'm'äjạnc, m’än'ca, p'ent', pu'l'änta, z'ent' ali in (<en) : guv'in'dar'in/ gov'en'dariin, sf' in't'ec;

$\leftarrow{ }^{*} Q$ v skupini z lal in pred nelabialnim soglasnikom: 'granda, gan'dzot, 'drank, 'kandu, 'kankul, 'mandru, 'manč, 'ranka 'vandz'il', 'vayg'il';

$\leftarrow$ sekundarno v nekaterih primerih v sekvenci ən: bənc, 'bənčfạ, 'dlanuk, lạn'dža, lạn'džica, lan'džahạ, lon'džička, 'mongla, 'rondži, s'tanglu in $\mathrm{v}$ p'in'tel, 'p'entuk.

$n$ ' ${ }^{*} n b$ : d'en', 'kamen';

$\leftarrow n$ po analogiji na koncu $\mathrm{v}$ posameznih primerih, na primer jur'gan, su'mun', v 1. os. ed. sed. pri glagolih tipa 'kaln'ạ.

$f \leftarrow h v$ : 'falbạ, 'faštạme;

$\leftarrow h$ v posameznih primerih: $k u$ 'žuf - ku'žufut, 'n'äftu, 'prafče, prạf'čul'če;

$\leftarrow v$ za nezvenečim soglasnikom, na primer 'žentfạ, k'lentfạ, s'mokfạ, 't’ikfạ, 'bənčfạ, sfat, sf' ät;

$\leftarrow$ analogno v enem primeru: 'lofut;

$\leftarrow$ onomatopejsko: 'fuči

$\leftarrow$ v prevzetih besedah: fạj'da, fạ'nar, fạ'sul', fạ'nela, f'il'džan, fus'tan.

$v \leftarrow \varnothing$ (kot proteza) pred refleks začetnega *o: 'vantur'i, 'vandži, 'vandz'il, 'vangl'i'nar'in.

$v^{\prime} \leftarrow{ }^{*} v j:$ 'd'iv'i, 'd'ivạk, mrạ'vička, m'rav'ạ, zd'raviil'zdrav'e.

$t \leftarrow{ }^{*} t$ ' v zaporedju št: 'došt'irạ, 'gašte, 'kəštạ, 'nošta, 'plaštạ, p'laštam, plậštaha, 'sf'ešta, 'sreešta, 'stréštạ;

$\leftarrow$ sekundarno v skupini sr: stram (tudi 'sram), st'r'ebru.

$t^{\prime} \leftarrow$ *tb: 'd'es'it'/d'es'et', z'ent', vendar 'zentufc'il z'entof'c'ite, p'ent', pant'- 'pant'u - pan'tička; 
$\leftarrow$ *tbj: 'brat'a;

$<*^{*}$ analogno v posameznih primerih, na primer pálat', iz'met'.

$d \leftarrow * d$ 'v zaporedju žd: do'žzaše, izvạ̌z'daše, 'mižž, 'paždạ, pạ'ždaše, 'sažda, 'v'äžda, zạ'graždane, zvạ'ždaše, 'zv'äžda.

$c$ ' * *'v 'c'äja 'sejem;

$\leftarrow * t^{\prime} \mathrm{v}$ 'c'ästu 'testo'.

$d z \leftarrow z$ stalno v skupini $n z$ : bạn'dzot, gạn'dzot, in'dz'ik, mun'dzura, 'pajạdz'i, 'vandzil, v posameznih primerih tudi pred samoglasnikom: 'budza, 'dzadna, nạ'dzat;

$\leftarrow d \mathrm{v}^{\prime}$ 'igam/dzigam $(<$ digam $)$.

$s^{\prime} \leftarrow s j:$ p'rosạk.

$z \leftarrow *_{z:}$ ' $z$ v'äžda.

$\check{c} \leftarrow *_{\breve{s}}$ v zaporedju $n \check{s}$ v manč $(<m \partial n \check{s}<$ manž);

$\leftarrow$ *t'v: 'čästu (< t'ästu), či'če (< tï̌ce), na primer či'če vodạ;

$\leftarrow c \mathrm{v}$ 'čerkfạta.

$d \check{\leftarrow} \leftarrow \check{z}$ v zaporedju nž: ạlan'džijạ, lạn'dža, lạn'džica, lạndži'čarn'ik, 'landže, 'mandža, 'mandžo (: mənč), pajin'džina, rạn'dži, tạn'džiš (*tož-), vạn'dža (*ože);

$\leftarrow$ prevzete besede: ạban'džijạ, b'il'džugạ, džam, džạ'mijiạ, džan'darmạs džum'buš, m’in'džit.

$\check{s} \leftarrow{ }^{*} t:$ : noš, p'l'eška, in v zaporedju št: 'gašte, 'kəštạ, nuš'ta, 'plaštạm, plạ'štaha, 'sf'eštạ, 'sr'eštạ, 'strešstạ, 'vr'eštạ;

$\leftarrow \check{c} \mathrm{v}$ zaporedju $p \check{c}:$ p'čela, přsito;

$\leftarrow s$ v posameznih primerih: l'i'šica (tudi l'i'sica), šl'äs, š'ternạ.

$\check{z} \leftarrow{ }^{*} d$ ' v zaporedju $\check{z} d:$ do'ždaše, izvadžzdaše, 'miždu, nạ'hožda, pu'miždu, 'saždu, 'paždạm, 'pažda, pa'.̌̌daše, 'v'äžda, 'zv'äžda, zvạ'ždaše.

$k^{\prime} \leftarrow$ prevzete besede: k'u'še, k'u't'ek', k'u'l'e;

$\leftarrow k$ na koncu prevzetih leksemov: ka'pajk'-ka'pac'i, k'urk', i'l'ejk'-i'l'ec'i.

g' $\leftarrow$ prevzete besede: 'g'ol', g'ạ'ur, g'em, g'ub're, g'u'l'uk.

$k<g$ po analogiji: b'r'äkut : br'äk(breg), p'lukuv'u : pluk (plug), lạł'kot : loyk (lang).

$h<s$ v zaporedju $s \check{c}$ v posameznih primerih, na primer $k^{\prime} r \partial h c ̌ a ~(: k r \partial s)$.

Poleg tega so zveneči nezvočniki pridobljeni iz ustreznih nezvenečih in nezveneči iz ustreznih zvenečih kot rezultat regresivne asimilacije glede na zvenečnost.

Nezveneči nezvočniki so nastali iz zvenečih tudi na izglasju.

\section{ProzodiJa}

Izhodiščni prozodijski sistem ni bil deležen nadaljnjih fonoloških sprememb, ampak le pomembnih morfoloških sprememb. 


\section{Izguba določenih glasov}

Nenaglašeni samoglasniki se v številnih primerih zaradi kvantitetne redukcije v večzložnih besedah izgubijo, na primer pun'd'äln'ik, t'fojtạ, 'l'ic'intạ, 'našta, b’iv'lica.

Samoglasnik /o/ se pogosto izgublja na začetku: 'paška, 'p’inc'i.

Fonem $/ v /$ se izgublja $\mathrm{v}$ redkih primerih $\mathrm{v}$ medsamoglasniškem položaju: 'klaạm, 'nou, 'ostai, pra'ime, 'hubajạ, p'rau. Na začetku pred labialnim soglasnikom je ohranjen: 'voda, vol, 'vosuk, vud'i'n'ica, 'vujku. Soglasniški sklop $v n$ - je poenostavljen: nuk, 'nuc'i, 'netre. Soglasniški sklop $t v>t f$ : 'tfoju, 'tfojtạ, u'tfor'i, čit'ratạk (četvratok), tudi v zaimkih: se, 'säkuj, 'säkutri.

Soglasnik / $t$ / se pogosto izgublja v izglasnih sklopih -st, - $p t$, na primer ' $z a-$ pos, 'sf'eš, 'šes.

Glas / $d$ / se izgublja v več primerih v medsamoglasniškem položaju: $k^{\prime} l a j a n c$, dạ v'ijm'i, zvaj, p'lajna (pladnina), v izpeljanih glagolih »ide«: poj, za-'pojm'i in v skupini $d n$ : pujno, pujna, nại'noš, 'panạ.

Fonem /h/ se izgubi v posameznih primerih, npr. l'ap, mo'una (mohuna).

$\mathrm{V}$ posameznih primerih se izgublja tudi $/ \mathrm{m} /$ : 'ijạm (imam).

\section{Sklepne ugotovitve}

Na glasoslovni ravni suškega govora se pojavljajo naslednje posebnosti:

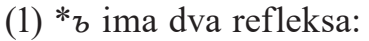

- la/ v korenskih morfemih: dəš', dəh, 'dənu, 'sən, 'snəhạ, 'dəska, 'məkn'ạ, 'sahnuvam in

- /o/ v obrazilih in členskih priponah za moški spol: dəž'do, gạ'nok, vạ'ko, d'en'd'i'no.

(2) $*_{b}$ ima $v$ naglašeni poziciji refleks /e/, ki se v nenaglašeni poziciji reducira $\mathrm{v} / \mathrm{i} / \mathrm{:}$ 'den : di'no.

(3) ${ }^{*} Q$ ima tri reflekse:

- /a/ v korenskem položaju: 'gaska, 'kəštạ, 'mətnu, 'rəka,

- /a/ v nekorenskem položaju: 'd'igạm, ot'ihạl, pr'i't'isạl,

- ohranjen nazalizem v obliki nazalnega soglasnika $/ \mathrm{m} /$ pred labialnimi soglasniki in nazalnega soglasnika $/ n /$ pred nelabialnimi soglasniki: dəmp, dlam'bok, 'gamba, 'kampạt, 'pəmp, 'romb'iš, 'skamp'i, 'sambutạl sam'bota, 'tampan, 'zəmp; 'vandz'il', 'vaygill, 'granda, gạn'dzot, 'dronk, 'kandu, 'kankul, 'məndru, 'mənč, 'rankạ.

(4) *e ima dva refleksa:

- /e/: 'mesu, p'et, pidis'et, dividis'et in

- ohranjen nazalizem v obliki nazalnega soglasnika $/ \mathrm{m} /$ pred labialnimi soglasniki in nazalnega soglasnika $/ n /$ pred nelabialnimi soglasniki: brạt'čend'i, en'trava, 'gl'enda, g'renda, k'l'entfạ, ko'l'enda, m’ins'íčina, magạ'rento, 'meyka, nạ'renduvam, 'p'enta, p'en'tata, p'ent', 'p'entuk, 'rent, 'endru, 'p'end'a, 'žentfạ, 'čendu, ir'en'b'icalirim'bica, 'zent. 
(5) *̌ ima refleksa:

- lä/ v naglašeni poziciji: bräk, 'b'ägạm, 'd'ädu, 'd'äte, 'l'äp, 'm’äso, 'säjme, s'änka, 'čov'äk, 'm'ästu, 'l'ätu in

- /e/ v posameznih primerih: 'vedru, vek, 'tera.

(6) *tj ima refleks:

- št: 'doštirira, 'kəštạ, p'laštạm, 'gašte, kə'šta, noštạ, 'plašta, plạ'štaha, 'sf'ešta, 'streštia, 'srešta.

(7) *dj ima refleks:

- žd: 'v’äžda, 'm’iždu, 'sažda, 'v'äžda, dz'ždaše, izvą̌اdaše, zạ'graždane, zvạ'ždaše, 'zv'äžda, 'paždạ, pạ'ždaše.

Vas Suho kaže visoko stopnjo podobnosti z govorom vasi Visoka, s katerim tvorita širši suško-visoški govor, ${ }^{7}$ ki se kot tak obravnava tudi v makedonski dialektologiji. Večja podobnost obstaja tudi med visoškim in zarovskim govorom, ki se zaradi glasovnih podobnosti obravnava kot širši visoško-zarovski govor $^{8}$ (Видоески 1999: 76-79, Марковиќ 2001: 140-144).

Refleksi, s katerimi je Vatroslav Oblak zagovarjal makedonsko teorijo o jezikovni osnovi stare cerkvene slovanščine (Oblak 1895: 237-246, 306-317), so tudi danes evidentirani na terenu v suškem govoru, in sicer:

$-\operatorname{razvoj} *_{b}>o$ in $*_{b}>e$,

- ohranjena nazalnost,

- refleks $\check{e}>\ddot{a}$,

- refleksa $* t j$ in $* d j>\check{s} t$ in $\check{z} d$.

Zadnji glasovni sovpad je tudi po mnenju več raziskovalcev (Oblak 1895, Jagić 1913, Šekli 2014) odločilen pri določitvi solunske osnove stare cerkvene slovanščine.

Vatroslav Oblak je leta 1891 pravilno zapisal reflekse, s katerimi je kasneje (1895: 237-246, 306-317) zagovarjal makedonsko teorijo o jezikovni osnovi stare cerkvene slovanščine. Kljub burni zgodovini Makedoncev se je makedonski suški govor ohranil in hrani reflekse, ki so pomembni za osvetlitev in prevetritev temeljnih vprašanj v slavistiki.

\section{LITERATURA}

Vanda BABIČ, 2003: Učbenik stare cerkvene slovanščine. Ljubljana.

Тодор ЧЕПРЕГАНОВ, 2008: Историја на македонскиот народ. Скопје.

\footnotetext{
${ }^{7}$ Visoški govor ima enake reflekse za $*_{b},{ }^{*} b,{ }^{*},{ }^{*} e, *_{e},{ }^{*} t j$ in $*^{*} j$ (Видоески 2000: 76-80).

${ }^{8}$ Zarovski govor ima enake reflekse za $*_{b},{ }^{*},{ }^{*} g, *_{e}, *^{*},{ }^{*} t j$ in ${ }^{*} d j$ (Вачева-Хотева, Керемидчиева 2000: 30-60).
} 
Josef DOBROVSKÝ, 1823: Cyrill und Method der Slawen Apostel. Ein historsch-kritischer Versuch. Prag.

Збигњев ГОЛОМБ, 1960/61: Два македонски говора (на Сухо и Висока во Солунско). Македонски јазик, XI-XII, кн. 1-2, 113-182. Скопје: Институт за македонски јазик.

- -, 1962/63: Два македонски говора (на Сухо и Висока во Солунско). Македонски јазик, XIii-XIV, кн. 1-2, 173-277. Скопје: Институт за македонски јазик.

Vatroslav JAGIĆ, 1900: Zur Entstehungsgeschichte der kirchenslavischen Sprache. Wien.

- -, 1913: Entstehungsgeschichte der kirchenslavischen Sprache. Berlin.

Marko JESENŠEK, 1998: Deležniki in deležja na -č in -ši. (Zora 5). Maribor: Slavistično društvo Maribor.

Bartholomeus KOPITAR, 1836: Glagolita Clozianus. Vindobonae. Ponatis s prevodom: Jerneja Kopitarja Glagolita Clozianus - Cločev Glagolit. Uredil in spremno besedo napisal Jože Toporišič, prevedel Martin Benedik. Ljubljana, 1995.

Mieczysław MAŁECKI, 1934: Dwie gwary macedońskie (Suhe i Wysoka w Soluńskiem) - Teksty. Krakow.

- -, 1936: Dwie gwary macedońskie (Suhe i Wysoka w Soluńskiem) - Stownik. Krakow.

Марјан МАРКОВИЌ, 2001. Дијалектологија на македонскиот јазик I. Скопје: Филолошки факултет »Блаже Конески«.

--, 2007: Дијалектологија на македонскиот јазик II. Скопје: Филолошки факултет »Блаже Конески«.

Franz MIKLOSICH, 1874: Altslovenische Formenlehre in Paradigmen mit Texten aus Glagolitischen Quellen. Wien.

Vatroslav OBLAK, 1895: Književno poročilo. Zgodovina slovenskega slovstva. I. del. Spisal prof. dr. Karl Glaser. V Ljubljani 1894, 80, XIV, 220, IV. Ljubljanski zvon 15, 237-246, 306-317.

- -, 1896: Macedonische Studien. Wien.

Matej ŠEKLI, 2014: Geolingvistična opredelitev stare cerkvene slovanščine v luči metodologije sodobnega primerjalnega jezikoslovja. Slovenski jezik na stičišču več kultur. Ur. Marko Jesenšek. (Mednarodna knjižna zbirka Zora, 102). Maribor: Mednarodna založba Oddelka za slovanske jezike in književnosti, Filozofska fakulteta, Univerza v Mariboru. 98-123.

Мария ВАЧЕВА-ХОТЕВА, Славка КЕРЕМИДЧИЕВА, 2000: Говорът на село Зарово, Солунско. София: Мултипринт Еоод.

Божидар ВИДОЕСКИ, 1998: Дијалектите на македонскиот јазик, m. 1. Скопје.

- -, 1999: Дијалектите на македонскиот јазик, т. 2. Скопје.

- -, 2000: Фонолошки бази на говорите на македонскиот јазик. Скопје: МАНУ. 
VIRI

Hellenic Statistical Authority. Dostopno 13. 4. 2015 na: http://www.statistics.gr/en/ home?p_p_id $=3 \& p \_p \_l i f e c y c l e=0 \& p \_p \_s t a t e=\operatorname{maximized} \& p \_p \_$mode $=v i e w \& \_3$ struts_action $=\% 2 \mathrm{Fsearch} \% 2 \mathrm{Fsearch} \& \_3$ redirect $=\% 2 \mathrm{Fen} \% 2 \mathrm{Fhome} \% 2 \mathrm{~F} \&$ _ 3 keyword $\mathrm{s}=\% \mathrm{CE} \% \mathrm{~A} 3 \% \mathrm{CE} \% \mathrm{BF} \% \mathrm{CF} \% 87 \% \mathrm{CF} \% 8 \mathrm{C} \% \mathrm{CF} \% 82 \&$ _3_groupId $=0$.

DM Brancoff, 1905: La Macedoine et Population chretienne. Paris. Dostopno 13. 4. 2015 na: http://anemi.lib.uoc.gr/php/pdf_pager.php?filename $=\% 2 \mathrm{Fvar} \% 2 \mathrm{Fwww} \% 2 \mathrm{Fa}$ nemi-portal\%2Fmetadata $\% 2 \mathrm{~F} 6 \% 2 \mathrm{~F} 9 \% 2 \mathrm{~F} 5 \% 2 \mathrm{Fattached}-$ metadata-5d3c137498cf87397 083652dec9dfdac_1242889374\%2F154547_w.pdf\&rec=\%2Fmetadata\%2F6\%2F9\%2F5 \%2Fmetadata-5d3c137498cf87397083652dec9dfdac_1242889374.tk1\&do=154547_w.pd f\&width $=1031 \&$ height $=728 \&$ pagestart $=1 \&$ maxpage $=141 \&$ lang $=$ en \&pageno $=1 \&$ pageno top=1\&pagenobottom $=5$.

Lazo MOÏSOV, Sur la question de la minorité nationale macédonienne en Grèce. Dostopno 13. 4. 2015 na: http://archive.is/jd2Qe.

THE PHONOLOGICAL BASE OF THE SUHO DIALECT - 120 YEARS AFTER THE PUBLICATION OF VATROSLAV OBLAK'S MACEDONISCHE STUDIEN (1896)

At the end of 1891 the Slovene philologist Vatroslav Oblak embarked on a study trip around southern Macedonia, where he investigated the dialects of the Solun area. He examined phonological reflexes in the dialect of the village of Suho near Solun, which are closely linked to Old Church Slavonic. According to Vatroslav Oblak, the following characteristics are most important: (1) the development of $b>o$ and $b>\mathrm{e}$ as one of the oldest Slavic manuscripts, (2) nasal articulation of the nasal vowel reflexes $x$ and $\mathbb{A}$, (3) the preservation of the consonant clusters $\check{s} t$ and $\check{z} d$ as in the Old Church Slavonic, (4) the lack of differentiation of the reflexes of the old $\mathbf{t}$ in ra. The final result was the propagation of the Macedonian theory, which is based on the fact that the brothers Saints Cyril and Methodius considered the spoken dialects from the vicinity of Solun as the basis of Old Church Slavonic, and with that, Oblak refuted the older Pannonian theory regarding the origin of Old Church Slavonic. Today the phonological base of the Suho dialect has the following phonological characteristics: (1) $*_{b}$ has two reflexes: /a/ in

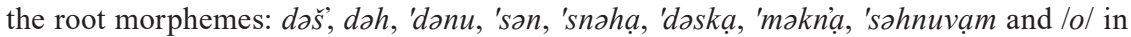
formants and articles marking male gender: dož'do, gar'nok, va'k'ko, d'en'd'i'no; (2) *b in accented position has reflex /e/, which in unstressed position is reduced to /i/: 'den : di'no; (3) * $Q$ has three reflexes: /a/ in root position: 'gaska, 'kəšta, 'mətnu, 'rəka; /a/ in non-root position: 'd'igam, ot'ihal, pr'i't'isal; preserved nasality in the form of a nasal consonant $\mathrm{m} /$ before labial consonants and nasal consonant $/ \mathrm{n} /$ before non-labial consonants: dəmp, dlam'bok, 'gamba, 'kamp'at, 'pamp, 'rambišs, 'skampii, 'sambutạ/səm'bota, 'təmpan, 'zəmp;

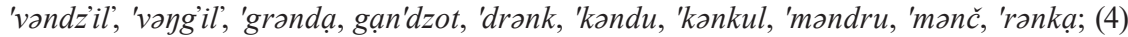
*e has two reflexes: /el: "mesu, p'et, pidis'et, dividis"et and preserved nasality in the form of a nasal consonant $/ \mathrm{m} /$ before labial consonants and nasal consonant $/ n /$ before nonlabial consonants: brat'čend'i, en'trava, 'gl'enda, g'renda, k'l'entfạ, ko'l'enda, minn'i'čina, maga'rento, 'meyka, na'r'enduvam, 'p'enta, p'en'tata, p'ent', 'p'entuk, 'rent, 'endru, 'p'end'a, 'žentfạ, 'čendu, iren'b'icạ/irim'bica, 'żent; (5) *ě has two reflexes: /ä/ in accented position: 
bräk, 'b'ägam, 'd'ädu, 'd'äte, 'l'äp, 'm'äso, 'säjme, 'sänka, 'čov'äk, 'm'ästu, 'l'ätu and lel v some examples: 'v'edru, vek, 't'era; (6) *tj has reflex /št/: 'došt'ira, 'kəšta, p'laštam, 'gašte, kə'šta, nošta, 'plašta, plạ'štahạ, 'sf'ešta, 'strieštạ, 'srešta; (7) *dj has reflex /žd/: 'v'äžda, 'm'iždu, 'sažda, 'v'äžda, do'ždaše, izvaž'daše, za'graždan'e, zvạ'ždaše, 'zv'äžda, 'pažda, pa'ždaše. The last two phonological mergers are also, according to several researchers (Oblak 1895, Jagić 1913, Šekli 2014) are characteristic of Old Church Slavonic. Vatroslav Oblak in 1891 correctly described the phonological base of the Suho dialect, which was later (1895: 237-246, 306-317) the core of his Macedonian theory about the Macedonian linguistic origin of Old Church Slavonic. Despite the turbulent history of the Macedonians, the Macedonian Suho dialect has preserved and retained reflexes that are important for illuminating fundamental issues in Slavic studies. 